\title{
Handbook of Research on Using Disruptive Methodologies and Game-Based Learning to Foster Transversal Skills
}

Irene Rivera-Trigueros

University of Granada, Spain

Abigail López-Alcarria

University of Granada, Spain

Diego-Pablo Ruiz-Padillo

University of Granada, Spain

María Dolores Olvera-Lobo

University of Granada, Spain

José Gutiérrez-Pérez

University of Granada, Spain 
Published in the United States of America by

IGI Global

Information Science Reference (an imprint of IGI Global)

701 E. Chocolate Avenue

Hershey PA, USA 17033

Tel: 717-533-8845

Fax: 717-533-8661

E-mail: cust@igi-global.com

Web site: http://www.igi-global.com

Copyright ( $) 2022$ by IGI Global. All rights reserved. No part of this publication may be reproduced, stored or distributed in any form or by any means, electronic or mechanical, including photocopying, without written permission from the publisher. Product or company names used in this set are for identification purposes only. Inclusion of the names of the products or companies does not indicate a claim of ownership by IGI Global of the trademark or registered trademark.

Library of Congress Cataloging-in-Publication Data

Names: Rivera-Trigeuros, Irene, 1993- editor. I López-Alcarria, Abigail, 1985- editor. I Ruiz, Diego, 1968- editor. I Olvera Lobo, María

Dolores, 1969- editor. I Gutiérrez-Pérez, José, 1963- editor.

Title: Handbook of research on using disruptive methodologies and game-based learning to foster transversal skills / Irene Rivera-Trigeuros, Abigail

López-Alcarria, Diego Ruiz, Maria-Dolores Olvera-Lobo, and José Gutiérrez-Pérez, editor.

Description: Hershey PA : Information Science Reference, [2022] I Includes bibliographical references and index. I Summary: "This book gathers knowledges, skills, abilities, and capabilities on innovative and disruptive methodologies that can be applied in all educational levels to foster transversal skills including game-based learning (gamification, educational Escape Rooms, etc.), online learning environments, collaborative learning, and project-based learning"-Provided by publisher.

Identifiers: LCCN 2021037613 (print) I LCCN 2021037614 (ebook) I ISBN 9781799886457 (hardcover) I ISBN 9781799886471 (ebook)

Subjects: LCSH: Soft skills--Study and teaching. I Educational games. I

Simulation games in education. I Gamification.

Classification: LCC HF5381 .U95 2022 (print) I LCC HF5381 (ebook) I DDC 650.1--dc23/eng/20211012

LC record available at https://lccn.loc.gov/2021037613

LC ebook record available at https://lccn.loc.gov/2021037614

This book is published in the IGI Global book series Advances in Game-Based Learning (AGBL) (ISSN: 2327-1825; eISSN: 2327-1833)

British Cataloguing in Publication Data

A Cataloguing in Publication record for this book is available from the British Library.

All work contributed to this book is new, previously-unpublished material. The views expressed in this book are those of the authors, but not necessarily of the publisher.

For electronic access to this publication, please contact: eresources@igi-global.com. 


\title{
Advances in Game-Based Learning (AGBL) Book Series
}

\author{
Robert D. Tennyson \\ University of Minnesota, USA \\ ISSN:2327-1825 \\ EISSN:2327-1833
}

\section{Mission}

The Advances in Game-Based Learning (AGBL) Book Series aims to cover all aspects of serious games applied to any area of education. The definition and concept of education has begun to morph significantly in the past decades and game-based learning has become a popular way to encourage more active learning in a creative and alternative manner for students in K-12 classrooms, higher education, and adult education. AGBL presents titles that address many applications, theories, and principles surrounding this growing area of educational theory and practice.

\section{Coverage}

- Curriculum Development Using Educational Games

- Digital Game-Based Learning

- Edutainment

- Electronic Educational Games

- Game Design and Development of Educational Games

- MMOs in Education

- Pedagogical Theory of Game-Based Learning

- Psychological Study of Students Involved in Game-

Based Learning

- Role of instructors

- Virtual worlds and game-based learning

The Advances in Game-Based Learning (AGBL) Book Series (ISSN 2327-1825) is published by IGI Global, 701 E. Chocolate Avenue, Hershey, PA 17033-1240, USA, www.igi-global.com. This series is composed of titles available for purchase individually; each title is edited to be contextually exclusive from any other title within the series. For pricing and ordering information please visit http://www.igi-global.com/ book-series/advances-game-based-learning/73680. Postmaster: Send all address changes to above address. Copyright @ 2022 IGI Global. All rights, including translation in other languages reserved by the publisher. No part of this series may be reproduced or used in any form or by any means - graphics, electronic, or mechanical, including photocopying, recording, taping, or information and retrieval systems - without written permission from the publisher, except for non commercial, educational use, including classroom teaching purposes. The views expressed in this series are those of the authors, but not necessarily of IGI Global.

IGI Global is currently accepting manuscripts for publication within this series. To submit a proposal for a volume in this series, please contact our Acquisition Editors at Acquisitions@igi-global.com or visit: http://www.igi-global.com/publish/. 


\section{Titles in this Series}

For a list of additional titles in this series, please visit: www.igi-global.com/book-series

\section{Esports Research and Its Integration in Education}

Miles M. Harvey (University of New Mexico, USA) and Rick Marlatt (New Mexico State University, USA)

Information Science Reference • ( $2021 \bullet 313 p p \bullet H / C$ (ISBN: 9781799870692) • US \$195.00

Exploring the Cognitive, Social, Cultural, and Psychological Aspects of Gaming and Simulations

Brock R. Dubbels (McMaster University, Canada)

Information Science Reference • ( $2019 \bullet 333 p p \bullet H / C$ (ISBN: 9781522574613) • US \$190.00

Design, Motivation, and Frameworks in Game-Based Learning

Wee Hoe Tan (Sultan Idris Education University, Malaysia)

Information Science Reference • ( $2019 \bullet 306 p p \bullet H / C$ (ISBN: 9781522560265) • US \$175.00

Handbook of Research on Collaborative Teaching Practice in Virtual Learning Environments Gianni Panconesi (Esplica, Italy) and Maria Guida (National Institute for Documentation, Innovation, and Educational Research, Italy)

Information Science Reference • C $2017 \bullet 637 \mathrm{pp} \bullet \mathrm{H} / \mathrm{C}$ (ISBN: 9781522524267) • US \$240.00

\section{Gamification-Based E-Learning Strategies for Computer Programming Education}

Ricardo Alexandre Peixoto de Queirós (uniMAD, Escola Superior de Media Artes e Design, Portugal) and Mário Teixeira Pinto (Polytechnic Institute of Porto, Portugal)

Information Science Reference • (C) $2017 \bullet 350 \mathrm{pp} \bullet \mathrm{H} / \mathrm{C}$ (ISBN: 9781522510345) • US \$200.00

\section{Handbook of Research on Serious Games for Educational Applications}

Robert Z. Zheng (University of Utah, USA) and Michael K. Gardner (The University of Utah, USA)

Information Science Reference • C $2017 \bullet 496 p p \bullet H / C$ (ISBN: 9781522505136) • US \$285.00

\section{Handbook of Research on 3-D Virtual Environments and Hypermedia for Ubiquitous Learning}

Francisco Milton Mendes Neto (Federal Rural University of the Semiarid Region, Brazil) Rafael de Souza (Federal Rural University of the Semiarid Region, Brazil) and Alex Sandro Gomes (Federal University of Pernambuco, Brazil) Information Science Reference • (C) $2016 \bullet 673 p p \bullet H / C$ (ISBN: 9781522501251) • US \$235.00

\section{Handbook of Research on Gaming Trends in P-12 Education}

Donna Russell (Walden University, USA) and James M. Laffey (University of Missouri at Columbia, USA)

Information Science Reference • C $2016 \bullet 663 p p \bullet$ H/C (ISBN: 9781466696297) • US \$325.00

\section{IGIGlobal}




\section{Editorial Advisory Board}

Cristobal Jorge Bañón, University of Granada, Spain

Melania Cabezas García, University of Granada, Spain

Cristina Cejudo Bastante, University of Cadiz, Spain

Mar Díaz Millón, University of Granada, Spain

Flory Dieck-Assad, Monterrey Institute of Technology and Higher Education, Mexico

María de Fátima Poza-Vilches, University of Granada, Spain

Gerardo Fernández Barbero, University of Cadiz, Spain

Marta Ferreira Dias, University of Aveiro, Portugal

Marta Ferreiro González, University of Cadiz, Spain

Miguel Ángel Gallardo Vigil, University of Granada, Spain

Pedro Antonio García Tudela, University of Murcia, Spain

Ángela Gómez López, University of Valencia, Spain

Leila Goosen, University of South Africa, South Africa

José Fernando Martín Villena, University of Granada, Spain

Judit Martínez Abajo, University of the Basque Country, Spain

Belén Massó Guijarro, University of Granada, Spain

Berta Murillo-Pardo, University of Zaragoza, Spain

Carmen Navarro Mateos, University of Granada, Spain

Laura Odila Bello, University of Veracruz, Mexico

Maria Elena Parra-González, University of Granada, Spain

Jorge Ramirez, Technical University of Madrid, Spain

Jessica Reuter, University of Aveiro, Portugal

Beatriz Revelles Benavente, University of Granada, Spain

Pablo Rodríguez-Díaz, University of Granada, Spain

Adrián Segura Robles, University of Granada, Spain

Mauricio Torres Martinez, Monterrey Institute of Technology and Higher Education, Mexico

Robert Zheng, University of Utah, USA 


\section{Preface}

Nowadays, the changing world is imposing on us accelerated updating trends that have a full impact both on our personal and professional spheres. Undoubtedly, these trends also affect the educational field, from early educational stages to the highest levels of the academic system. Consequently, the democratization and universalization of the learning and teaching process have involved moving the center of power and attention to other agents, contexts and means that are no longer the teacher, the school and formal learning. As a result of these transformation, during the last decades, spontaneity, experimentation, inquiry, and individual and shared discovery have been taking the lead and giving rise to educational methodologies focused on meaningful learning (Ausubel, 1963), discovery learning (Bruner, 1961), service-learning (Furco, 1996) or problem-based learning (Barrows, 1996), to name but a few. It is within the framework of these disruptive scenarios of individual building of knowledge and social construction of science that all these methodological advances are framed.

On the other hand, it is undoubtable that the relentless advance of technology is shaping today's society, in which everyone can have access to a world of possibilities, culture and information by simply by taking their mobile phones out of their pockets (Lipovetsky \& Serroy, 2007; Rifkin, 2001). As a result, the continuous development of Information and Communication Technologies (ICTs) greatly diversify pedagogical tools and establish cyclical patterns of rupture that force teaching professionals to continually update themselves. These demands go far beyond of becoming familiar with new interaction formats and typologies of activities. They entail awareness of the framework of fundamentals and the training potential, based on empirical evidence, of the disruptive methodologies that are bursting into the educational field. Therefore, there is a remarkable need to make sense of the pedagogical and methodological innovations and to be aware of their advantages and disadvantages. To meet this aim, it is essential to count on contrasted research results which allow to incorporate creative ways of learning assessment in its conceptual, procedural, and attitudinal facets.

In addition, it is important to note that today, out-of-school and non-formal learning spaces (Eshach, 2007) - such as museums, science parks, sports and music clubs or informal virtual spaces, among others - are gaining ground and many of their work methodologies are often transferred to formal educational institutions as innovations that are in line with the interests, digital skills and technological habits of the new generations. Moreover, these spaces allow for co-generative thinking models, providing alternative paths for intellectual development and promoting multiple intelligences, collaborative values, inclusive and sustainable behaviors, and local and global solidarity while fostering lifelong learning (Braund \& Reiss, 2006; Eshach, 2007). Therefore, it is important for educators, trainers and all the actors involved in education not to ignore these renewed and transgressive scenarios as they provide valuable opportunities for educational updating. 
At this point, it is important to define what it is understood for innovation and disruptive innovation. On the one hand, innovation is defined as the successful exploitation of new ideas (Del Moral Pérez \& Férnandez García, 2015), whereas disruptive innovation is aimed on challenging what has been previously established (Christensen et al., 2015). Focused on the educational field, disruptive innovation means challenging and redefining traditional methodologies (Cobo, 2016). Consequently, disruptive pedagogies frequently involve changing the roles of teachers and students, the effective implementation of ICTs and the promotion of transversal skills such as collaboration, critical thinking and creativity, among others (Burden et al., 2019). To summarize, disruptive innovation in education should imply the design of new student-centered teaching methodologies, far from traditional methods, greatly supported by ICTs and encouraging students to acquire and develop transversal skills (Díaz-Millón et al., 2020).

In this regard, according to the Tuning Educational Structures in Europe project (González \& Wagenaar, Eds. 2003), transversal skills involve the acquisition of cross-disciplinary skills during the teaching and learning process. As a result, fostering transversal skills, such as those recently mentioned, will allow students to acquire competencies that would be of great use for their future, specially, when it comes to access a labor market, which is in constant change and demand for continuous updating and adaptation. Nevertheless, despite their paramount importance, transversal skills have often a secondary role in the school curriculum (Olvera-Lobo et al., 2018). To overcome this situation, given that fostering transversal skills requires methodologies and assessment processes focused not only on the development of a final product, but on the whole process involved, disruptive methodologies profile themselves as a great ally to meet this aim (Hansen-Schirra et al., 2017).

In the light of the previously described scenario, the purpose of this book is to provide practical skills that contribute to modernize, update and promote the professional development of educators, teachers, trainers, academic and researchers within the different levels of the educational system.

\section{TARGET AUDIENCE OF THE BOOK}

The experiences shown in the different chapters of this manual illustrate in a very clarifying way the advances of innovation and research in the use of disruptive methodologies applied to multiple topics and learning ecosystems.

This book deals with a great variety of topics revolving around transversal skills and disruptive methodologies, with a special focus on game-base methodologies, more specifically, educational escape rooms. Given the information contained in this book, its target audience is composed of academics, professionals and researchers working at all levels in the educational field who aim to overcome traditional paradigms' obstacles and meet students' needs by means of implementing innovative and disruptive technologies.

\section{BOOK OUTLINE}

This book is composed by 21 chapters organized into four broad sections. The first section, "Approaching Disruptive Methodologies," is composed by two chapters. This section aims to offer a general overview of disruptive methodologies in education.

Chapter 1, "Teachers Using Disruptive Methodologies in Teaching and Learning to Foster Learner Skills: Technological, Pedagogical. and Content Knowledge," introduces a project which investigates 
in what ways teachers are using disruptive methodologies in teaching and learning to foster learners' transversal skills and provides readers with an overview of the Technological, Pedagogical and Content Knowledge (TPACK) framework for teachers.

Chapter 2, "Disruptive Unicorn of Digital Innovations: A Challenge for University Professors," analyzes six of the most important disruptive innovations. To this aim, the author explores the perceptions of undergraduate students concerning these innovations and the risks they could generate with regard to ethics and business power shifts in the world. This chapter remarks the importance of transversal skills such as critical thinking when it comes to disruptive innovations in the educational field.

The second section, "Disruptive Methodologies in Practice: Learning Communities, Task and GameBased Learning," includes five chapters, dealing with disruptive methodologies, in particular, Learning Communities, task-based learning, gamification and game-based learning.

Chapter 3, "Implementing Learning Communities in a Medical School: How We Built, Executed, and Embraced a New Model for Medical Education," deals with the implementation of Learning Communities in undergraduate medical education. The authors explore the technical aspects, the challenges and solutions of the model and reflect on the learning experiences gained during more than six years since the model implementation. It is important to note that the approach proposed by the authors promote interaction among the educational agents involved and it has a positive impact on the personal and professional development of the students.

Chapter 4, "Transcreation and Creativity in Higher Education: A Task-Based Learning Experience in the Undergraduate Program of Translation and Interpreting," explores new professional profiles which have recently emerged in the translation sector, such as transcreation. The chapter presents a task-based learning experience, aimed at promoting the transversal skills involved in the transcreation process, and implemented in an undergraduate translation course. The empirical analysis of this experience showed that it served students to display transversal skills such as creativity or decision-making.

Chapter 5, "Theoretical Overview of the Game in Education and an Innovative Proposal in Higher Education," deals with the growing academic interest in Game Based Learning (GBL). To do so, the author presents the theory and practice of serious games and GBL and explore gamification in depth by means of analyzing its most significant theoretical findings, well-known frameworks, and current experiences in higher education. The chapter concludes with an illustrative example of a digital escape room implemented with education undergraduate students.

Chapter 6, "Foster Transversal Skills in Game-Based Learning: A Deep Learning Approach," examines the relationship between facets of cognitive abilities and relevant learning activities with a special focus on cognitive architecture and deep learning, modality and information process and cognitive abilities and levels of process in learning activities. In this sense, the author proposes the cognitive ability-learning matrix and discuss its theoretical and practical significance.

Chapter 7, "MasterchEF: A Talent Show-Based Educational Project for the Training of Future Physical Education Teachers," presents a learning experience based on a famous cooking TV show and built using active methodologies that turned students into the protagonist of the learning process. The participants students had to face different challenges based on the course contents which promoted skills such as decision making or emotional management.

The third section, "Disruptive Methodologies Aimed to Sustainable Development Goals," is composed by six chapters addressing such important themes as climate change and sustainability in education by means of disruptive methodologies. 
Chapter 8, "Active Methodologies in Education for Sustainability and Development of Action Skills," is focused on the importance of active methodologies in education for sustainability in non-university levels. The chapter conceptualizes active methodologies and describe their origins, evolution, potentialities, and limitations from the perspective of neuroeducation and constructivism.

Chapter 9, "Disruptive Methodologies in Eco-Centers: Sustainability Audit as a Tool for Detecting Needs in Participatory Processes," explores the use of Sustainability Audits through participatory action research in order to analyze the situation of educational centers in environmental matters. The authors also analyze how these audits contribute to foster participatory attitudes and behaviors among the communities involved from Early Childhood to Higher Education, with a special focus on students.

Chapter 10, “'La Voz del Rehén': An Interdisciplinary Approach to the Development of Creativity in Pre-Service Teacher of Physical Education - Towards Collective Learning Models for Unlocking the SDGs," describes the interdisciplinary program, La Voz del Rehén, based on the sustainable development goals. This program intends to foster students' transversal skills such as creativity and to stimulate learning process from collective involvement.

Chapter 11, "Dramatizing the Climate Emergency: Thinking up New Cultural Mediators in Environmental Education," presents the project RESCLIMA, which is centered upon research on social representations of climate change. During the chapter, the authors present the steps taken during the project, which range from the development of educational activities to the production of a theatrical play and theater workshops.

Chapter 12, "Project-Based Learning a Climate Change Education Proposal in Contexts of Inequality and Vulnerability," presents a program focused on climate change education in Mexico articulated around multidisciplinary knowledge on climate change and adaptation and mitigation response action. The authors describe the design, analysis and results of a course workshop as well as follow-up actions in the implementation of climate change education practices.

Chapter 13, "Educational Innovation to Address Climate Change Issues: The Emerging Trend of (Online) Escape Rooms," explores the application of educational escape rooms to engage students in their learning environment. First, the authors present a revision of literature in this domain and then they present a case study focused on an escape room entitled Escape Global Warming, which integrates the core concepts of climate change and global warming.

Finally, the fourth section, "Educational Escape Rooms," includes eight chapters entirely focused on the emerging trend of escape rooms as an educational disruptive methodology. While the theme of escape rooms has been already introduced in the book, this section explores in depth this educational trend thanks to the eight chapters included, which present different escape rooms implemented in diverse educational levels and fields.

Chapter 14, "The Use of the Escape Room as a Methodology for the Development of Professional Skills in the Training of Future Teachers: Active Methodologies and Development of Skills in Future Teachers," outlines how to use an Escape Room as a training strategy for developing socio-emotional, sustainable and multi-intelligence approaches. This chapter illustrates how this emerging methodology favors students' motivation, the acquisition of skills and the consolidation of theoretical contents.

Chapter 15, "Gamification and Escape Room for Learning: A Practical Proposal for Primary Education," revolves around the use of gamification and Escape Rooms as educational methodologies to be implemented in Primary Education. To illustrate the importance of these methodologies, the authors propose an intervention targeted at primary education students and whose main axis is an escape room. 
Chapter 16, "Using Escape Rooms to Improve Pre-Service Teachers' Communicative Skills in English as a Foreign Language," is focused on the implementation of an Escape Room in the degree of Childhood and Primary Education. Fifty-seven undergraduate students participated in the Escape Room, which had been designed by ten of the students. In addition, the author distributed self-administered questionnaires among the participant students to analyze their perceptions about using escape rooms as a learning resource and results showed that this tool fosters active learning, teamwork, socialization, motivation, and communication skills.

Chapter 17, "Physical, Hybrid and Digital Escape Rooms: Using EERGs in the Translation Classroom Through Literature," describes three study cases focused on escape rooms and implemented in the Literature classroom. During the chapter, the author offers a theoretical and methodological framework about affective pedagogies and describe solutions and recommendations for the encountered challenges while implementing the escape rooms.

Chapter 18, "EscapeWine! A Fusion of Game-based Activities for the Virtual Learning Process in Bachelor's Degree in Enology," proposes an online activity targeted to undergraduate students of Enology. This activity aimed to help students to contextualize concepts and to strengthen transversal skills by providing them a motivating environment where they had to solve different riddles in a virtual platform. The findings show that the activity has a great potential to be implemented in virtual lessons.

Chapter 19, "A Digital Escape Room for Learning General Physics in HEIs: Building the Universe in Five Rooms," shares an experience of design, creation, implementation, and evaluation of a digital escape rooms aimed at learning Physics. The authors, from the literature review and the reflection of their own experience, provide practical advice for future design, implementation, and evaluation of escape rooms.

Chapter 20, "Design and Implementation of an Escape Room About the Discovery of the Periodic Table," is focused on the description of an escape room intended to commemorate the International Year of the Periodic Table, which was designed to foster transversal skills such as teamwork and creativity of high school students aged from fifteen to eighteen as well as undergraduate students. The authors explain in detail the most important aspects, such as riddles, settings, and the story, to be taken into account when designing an Escape Room

Chapter 21, "Challenges in the Application of Educational Escape Rooms in the Brazilian Context," presents a study carried out with Brazilian higher education teachers about the use of educational escape room in the classroom. The results of the study outline the importance of the institutional support for teachers to feel comfortable when implementing educational escape rooms. During this chapter, the authors provide valuable conclusions about the best practices concerning the implementation of educational escape rooms.

\section{CONCLUSION}

We, as editors, are aware that this book may pose more questions than answers, specially taking into account the new change of paradigm in education caused by the COVID-19 pandemic. However, it is important to remark that the desire for learning is an intrinsic feature of the human beings which is no subjected to limits. Consequently, the chapters included in the present volume clearly show the advances of innovation and research concerning disruptive methodologies. As the book outline shows, the contributions included in this volume describe a great revolution in the educational and academic field and give a great testimony of the individual and collective advances in the educational sphere. 
On the other hand, throughout the book, the challenges and the obstacles posed by traditional methodologies are also illustrated and solutions and recommendations are suggested in order to overcome them. It is true that, as teachers and educators, it is easier to remain in the comfort zone provided by traditional teaching methodologies rather than being exposed to the uncertainty of taking innovative paths. However, even if we are aware of the implicit risks, we, as editors and educators, would like to encourage the readers of the present volume to take on these new educational experiences which included, among many others, learning communities, task and problem-based learning, simulated learning or gamification and escape rooms.

We are sure that these approaches will allow educators, teachers, and students to acquire new innovative skills that will mean an added value to the teaching and learning process. Moreover, the competences and knowledge acquired are not only limited to formal education and the classroom, given that these methodologies and tools, if applied successfully, also allow to train better professionals and citizens who will be able to be agents of change to build a more rational, creative, sustainable, equitable and inclusive world.

On another note, the editors are members of the project UNLOCK - Creativity in Higher Education Institutions through a game design approach (Ref. 612645-EPP-1-2019-1-PT-EPPKA2-KA) coordinated by Marta Ferreira Dias, from the University of Aveiro. This project aims to equip HEIs with the necessary knowledge, attitudes and skills to design, set and facilitate escape room games in learning experiences and stimulate entrepreneurial skills of both students and educators, with the objective of strengthening employability, creativity and new career paths.

Our work within the framework of the project served as motivation for us to undertake the edition of this volume in which many different academic and professional backgrounds converge.

Finally, we, as editors of the book, hope that the readers of this volume will delight in the reflections and experiences shared throughout the twenty-one chapters as much as we have enjoyed and learned during the editing process.

Irene Rivera-Trigueros

University of Granada, Spain

Abigail López-Alcarria

University of Granada, Spain

Diego-Pablo Ruiz-Padillo

University of Granada, Spain

María-Dolores Olvera-Lobo

University of Granada, Spain

José Gutiérrez-Pérez

University of Granada, Spain 


\section{REFERENCES}

Ausubel, D. (1963). The psychology of meaningful verbal learning. Grune \& Stratton.

Barrows, H. S. (1996). Problem-based learning in medicine and beyond: A brief overview. New Directions for Teaching and Learning, 1996(68), 3-12. doi:10.1002/t1.37219966804

Braund, M., \& Reiss, M. (2006). Towards a More Authentic Science Curriculum: The contribution of out-of-school learning. International Journal of Science Education, 28(12), 1373-1388. doi:10.1080/09500690500498419

Burden, K., Kearney, M., Schuck, S., \& Hall, T. (2019). Investigating the use of innovative mobile pedagogies for school-aged students: A systematic literature review. Computers \& Education, 138, 83-100. doi:10.1016/j.compedu.2019.04.008

Christensen, C. M., Raynor, M. E., Rory, M., \& McDonald, R. (2015). What is disruptive innovation. Harvard Business Review, 93(12), 44-53. doi:10.1353/abr.2012.0147 PMID:17183796

Cobo, C. (2016). La Innovación Pendiente. Reflexiones (y Provocaciones) sobre educación, tecnología y conocimiento. In Virtualidad, Educación y Ciencia(Vol. 7, Issue 13). Colección Fundación Ceibal/Debate.

Del Moral Pérez, M. E., \& Férnandez García, L. C. (2015). Videojuegos en las aulas: Implicaciones de una innovación disruptiva para desarrollar las Inteligencias Múltiples. Revista Complutense de Educación, 97(26), 1130-2496. doi:10.5209/rev_RCED.2015.v26.44763

Díaz-Millón, M., Rivera-Trigueros, I., Olvera-Lobo, M. D., \& Gutiérrez-Artacho, J. (2020). Disruptive Methodologies and Cross-Curricular Competencies for a Training Adapted to New Professional Profiles. In S. Palahicky (Ed.), Enhancing Learning Design for Innovative Teaching in Higher Education (pp. 83-104). IGI Global. doi:10.4018/978-1-7998-2943-0.ch005

Eshach, H. (2007). Bridging in-school and out-of-school learning: Formal, non-formal, and informal education. Journal of Science Education and Technology, 16(2), 171-190. doi:10.100710956-006-9027-1

Furco, A. (1996). Service-Learning: A Balanced Approach to Experiential Education. Service Learning, General, 128.

Hansen-Schirra, S., Hofmann, S., \& Nitzke, J. (2017). Acquisition of generic competencies through project simulation in translation studies. In Positive Learning in the Age of Information: A Blessing or a Curse? (pp. 267-280). Springer Fachmedien Wiesbaden. doi:10.1007/978-3-658-19567-0_16

Lipovetsky, G., \& Serroy, J. (2007). L’ Ecran global. Seuil.

Olvera-Lobo, M. D., Robinson, B. J., \& Gutiérrez-Artacho, J. (2018). Generic Competences, the Great Forgotten: Teamwork in the Undergraduate Degree in Translation and Interpretation. World Academy of Science, Engineering and Technology, 12(11), 4190-4194.

Rifkin, J. (2001). The Age of Access: The New Culture of Hypercapitalism, Where all of Life is a PaidFor Experience. Tarcher. 